\title{
Anti-Oxidative and Anti-Inflammatory Effects of the Solvent Fraction from Theobroma cacao L. Extract
}

\author{
Young-Sun Kim ${ }^{1}$, Jin-Young Lee ${ }^{2}$, Young-Je Cho ${ }^{3}$ and Bong-Jeun $\mathrm{An}^{1}{ }^{*}$ \\ ${ }^{1}$ Department of Cosmeceutical Science, Daegu Haany University, Gyeongbuk 712-715, Korea \\ ${ }^{2}$ Department of Herbal Cosmetic Science, Hoseo University, Chungnam 336-795, Korea \\ ${ }^{3}$ School of Food Science \& Biotechnology, Food \& Bio-Industry Research Institute, Kyungpook National University, Daegu 702-701, Korea
}

Received July 9, 2012 /Revised October 4, 2012 /Accepted October 8, 2012

\begin{abstract}
Solvent extracts of Theobroma cacao L. (TCL) were investigated for anti-oxidative and anti-inflammatory effects in order to consider TCL as a functional ingredient for cosmetic products. TCL(A) extract was fractioned according to polarity with $\mathrm{CHCl}_{3}$, EtOAc, n-BuOH, and water. Following TCL(A) fractionation, the electron-donating ability of the $\mathrm{n}-\mathrm{BuOH}$ and EtOAc solvent fractions (each $100 \mu \mathrm{g} / \mathrm{ml}$ ) was about $76.2 \%$ and $53.9 \%$, respectively. The superoxide anion radical inhibitory effect of the $\mathrm{n}-\mathrm{BuOH}$ and EtOAc solvent fractions (each $50 \mu \mathrm{g} / \mathrm{ml}$ ) was about $76.09 \%$ and $51.4 \%$, respectively. Results of lipid oxidation showed that $\mathrm{Fe}^{2+}$ had a greater chelating effect than $\mathrm{Cu}^{2+}$. The $\mathrm{Fe}^{2+}$ chelating effect of the EtOAc solvent fraction $(50 \mu \mathrm{g} / \mathrm{ml})$ was about $64 \%$. Hyaluronidase inhibition related to the anti-inflammatory effect was $53.0 \%$ with EtOAc at $100 \mu \mathrm{g} / \mathrm{ml}$, while the lipoxygenase inhibitory effect was about $51.32 \%$ at $10 \mu \mathrm{g} / \mathrm{ml}$. The anti-inflammatory activity in the EtOAc fraction inhibited the generation of nitric oxide. Results also showed that iNOS protein expression increased in RAW264.7 cells. In contrast, at $100 \mu \mathrm{g} / \mathrm{ml}$ EtOAc, iNOS and COX-2 protein expression significantly decreased in LPS-stimulated RAW 264.7 cells.
\end{abstract}

Key words : Anti-oxidative, anti-inflammatory, iNOS, COX-2, Theobroma cacao L.

\section{서 론}

피부는 자외선, 환경독성 물질 등에 직접 노출되어 발생하 는 활성산소와 염증 발생이 다른 조직에 비해 매우 높은 편이 며, 최근 오존층 파괴 및 수질 오염 등의 환경 요인의 증가에 의해 피부 노화 및 염증의 발생 속도가 빨라지고 있다[21]. 천 연 추출물은 현대인의 스트레스와 오염된 환경에서 오는 노화 된 피부에 효능을 부여하는 신소재로서, 자연주의, 저자극성 화장품이라는 이미지 등으로 웰빙에 부합하고 있다. 이들은 각종 천연식물에서 추출한 생리활성 물질들로 항노화 효과, 미백효과와 피부 자극 완화 효과가 우수하여 다양한 식물추출 물에서 발견되고 개발되어, 그 효능이 끓임 없이 연구를 통해 알려지고 있다[15,16].

카카오(Theobroma cacao L.)는 무덥고 습한 기후에서 잘 자 라며 씨를 심어서 3 4년만에 열리기 시작하여 10 20년 자라면 가장 많이 열리고 40 년이 지나면 늙어버린다. 카카오라는 이 름은 원래 나무의 이름이나 발효되지 않은 pod를 언급할 때 사용하였으나 최근에는 카카오나무의 열매를 따서 씨만을 꺼 내어 3 9일간 $45^{\circ} \mathrm{C}$ 이하에서 적당히 발효시켜 만든 성숙한 씨를 지칭한다[1]. 씨(cacao bean)에는 1.3 2\%의 알칼로이드,

*Corresponding author

Tel : +82-53-819-1429, Fax : +82-53-819-1429

E-mail : anbj@dhu.ac.kr
$45 \sim 58 \%$ 의 유지가 있다. 이 외에도 $16.5 \%$ 의 starch, $15 \%$ 의 protein, phenolic acid, anthocianin, leucoanthocianin, purin, tannin, theobromin 등 다수의 성분들이 함유되어 있는 것으 로 알려져 있다. 또한 카카오에는 피부노화를 방지해 주는 폴 리페놀 성분이 녹차나 와인에 비해 더 많이 함유되어 있으며, 카카오에 함유된 비타민과 아미노산은 피부의 보습효과, 항염 작용, 항산화 작용을 하는 것으로 알려져 있다[21,30].

본 연구에서는 카카오의 폴리페놀 함량을 분석하고, 용매 분획하여 항산화 및 항염증 효과를 검증하여 천연화장품 소재 로서의 가능성을 검토하고자 한다.

\section{재료 및 방법}

\section{재료}

본 실험에 사용한 카카오(Theobroma cacao L.)는 가나산 카 카오를 (주)롯데 식품사업부에서 시판되고 있는 원료를 롯데 그룹 중앙 연구소에서 공급받아 실험재료로 사용하였다.

\section{시료 추출 및 용매분획}

카카오 $10 \mathrm{~kg}$ 을 $70 \%$ 아세톤을 가하여 상온에서 1주일간 3회 추출한 다음 filter paper (Whatman No. 2)로 여과하였고, 얻어진 여액은 감압 농축하여 아세톤 추출물을 얻었다. 이 아 세톤 추출물의 극성 차를 이용해 서로 다른 용매를 첨가하여 
단계적으로 분획하였다. 카카오 아세톤 추출물과 클로로포름 을 1:1 비율로 분획 깔대기에 넣고 클로로포름층과 물층을 분 획하였고, 클로로포름층을 다시 감압 농축하여 분획물 21.92 $\mathrm{g}$ 을 얻었다. 동일한 과정을 통해 에틸아세테이트층 $(35.44 \mathrm{~g})$, 부탄올층 $(40.08 \mathrm{~g})$, 물층 $(46.55 \mathrm{~g})$ 을 순차적으로 가하여 각 분획 물을 얻었다. 이들 분획물들을 감압, 농축 후 동결 건조하여 용매를 제거한 후 실험에 사용하였다.

\section{총 폴리페놀 함량 측정}

폴리페놀 정량은 $\mathrm{AOAC}$ [2]에 준하여 정량하였다. 즉, 100 배 희석한 시료용액 $3 \mathrm{ml}$ 에 folin-ciocalteu phenol reagent 시 약 $1 \mathrm{ml}$ 를 가하고, $1 \mathrm{~N} \mathrm{HCl} 0.2 \mathrm{ml}$ 을 넣은 후, 포화용액 $\mathrm{Na}_{2} \mathrm{CO}_{3}$ $1 \mathrm{ml}$ 를 가하여 혼합한 후 1 시간 실온에서 방치하고, $640 \mathrm{~nm}$ 에 서 흡광도를 측정한 후, 표준물질인 tannic acid로 미리 작성한 표준곡선의 흡광도 값과 비교하여 폴리페놀 함량을 산출하였다.

\section{전자공여능 측정}

전자공여능(electron donating ability, EDA)은 Blois의 방법 [3]을 변형하여 측정하였다. 각 시료용액 $2 \mathrm{ml}$ 에 $0.2 \mathrm{mM}$ 의 1,1-diphenyl-2-picrylhydrazyl (DPPH) $1 \mathrm{ml}$ 넣고 교반한 후 30 분간 방치한 다음 $517 \mathrm{~nm}$ 에서 흡광도를 측정하였다. 전자공 여능은 시료용액의 첨가군과 무첨가군의 흡광도 감소율로 나 타내었다.

$$
\text { 전자공여능 }(\%)=\left(1-\frac{\text { 시료첨가군의 흡광도 }}{\text { 무첨가군의 흡광도 }}\right) \times 100
$$

\section{Superoxide anion radical 소거능 측정}

Superoxide anion radical 소거능은 nitroblue tetrazolium (NBT) 환원방법에 의해 측정하였다[12]. 각 시료용액 $0.1 \mathrm{ml}$ 와 $0.1 \mathrm{M}$ potassium phosphate buffer $(\mathrm{pH} 7.5) 0.6 \mathrm{ml}$ 에 xanthine $(0.4 \mathrm{mM})$ 과 $\mathrm{NBT}(0.24 \mathrm{mM})$ 을 녹인 기질액 $1 \mathrm{ml}$ 를 첨가하고 xanthine oxidase $(0.049 \mathrm{U} / \mathrm{ml}) 1 \mathrm{ml}$ 를 가하여 $37^{\circ} \mathrm{C}$ 에서 20 분 간 반응시킨 후 $1 \mathrm{~N} \mathrm{HCl} 1 \mathrm{ml}$ 를 가하여 반응을 종료시킨 다음, 반응액 중에 생성된 superoxide anion radical의 양을 $560 \mathrm{~nm}$ 에서 흡광도를 측정하였다.

$$
\text { 저해율 }(\%)=\left(1-\frac{\begin{array}{c}
\text { 시료첨가군의 superoxide anion } \\
\text { radical 생성량 }
\end{array}}{\begin{array}{c}
\text { 무첨가군의 superoxide anion } \\
\text { radical 생성량 }
\end{array}}\right) \times 100
$$

지방산패 억제능 측정을 위한 fish oil emulsion 조제

지방산패 억제능 실험에 사용하는 oil emulsion은 실험직전 에 만들었으며, 미리 pH 6.5로 보정한 $0.1 \mathrm{M}$ maleic acid buffer $8 \mathrm{ml}$ 를 넣은 다음 $0.05 \mathrm{ml}$ 의 유화제인 tween- $200.05 \mathrm{ml}$ 와 $0.25 \mathrm{ml}$ 의 fish oil을 넣고 15 분간 교반하였다. 이 후 $\mathrm{KOH} 2$ $\mathrm{g}$ 을 넣고 $150 \mathrm{ml}$ 까지 정제수를 가한 후 교반하면서 $2 \mathrm{~N} \mathrm{HCl}$ 로 $\mathrm{pH}$ 6.5가 되도록 조제하여 사용하였다.

$\mathrm{Fe}^{2+}, \mathrm{Cu}^{2+}$ 의 첨가에 따른 지방 산패 억제도 측정

산화 촉진제인 $\mathrm{Fe}^{2+}, \mathrm{Cu}^{2+}$ 의 첨가에 따른 지방 산패 억제도 측정은 Buege와 Aust의 방법[4]에 따라 측정하였다. 미리 조 제된 oil emulsion $0.5 \mathrm{ml}$ 와 시료 $0.1 \mathrm{ml}$ 및 $50 \mathrm{ppm}$ 의 $\mathrm{Fe}^{2+}$ 또는 $\mathrm{Cu}^{2+}$ 이온용액 $0.1 \mathrm{ml}$ 가 포함된 혼합물이 채워진 시험관 을 $37^{\circ} \mathrm{C}$ 에서 1 시간 동안 반응시킨 후 $2 \mathrm{ml}$ 의 trichloracetic acid (TCA) / 2-thiobarbituric acid (TBA) 시약을 가하고 다시 혼합 후 끊는 물에서 15 분간 끊인 다음 $5,000 \mathrm{rpm}$ 에서 10 분간 원심분리 시켜 상층액을 흡광도 $531 \mathrm{~nm}$ 에서 측정하였다. $\mathrm{Fe}^{2+}$, $\mathrm{Cu}^{2+}$ 의 첨가에 따른 지방 산패 억제도는 시료용액의 첨가군과 무첨가군의 흡광도 감소율로 나타내었다.

$$
\text { 저해율 }(\%)=\left(1-\frac{\text { 시료첨가군의 흡광도 }}{\text { 무첨가군의 흡광도 }}\right) \times 100
$$

\section{Hyaluronidase 저해활성 측정}

Hyaluronidase (HAase) 저해활성 측정은 sodium-hyaluronic acid (HA)로부터 형성된 N-acetylglucosamine을 glucoxazoline 유도체로 변형시킨 후 p-dimethylaminobenzaldehyde (DMAB)로 발색시켜 흡광도를 측정하여 효소 활성을 측정하였다[10]. $0.1 \mathrm{M}$ acetate buffer ( $\mathrm{pH}$ 3.5)에 녹인 HAase $(7,900 \mathrm{U} / \mathrm{ml}) 0.05 \mathrm{ml}$ 와 시료용액 $0.1 \mathrm{ml}$ 를 혼합하여 $37^{\circ} \mathrm{C}$ 에서 20 분간 배양한 다음 $12.5 \mathrm{mM} \mathrm{CaCl} 20.1 \mathrm{ml}$ 를 가하고 혼합 후 다시 20 분간 배양하였다. 기질로서 $0.1 \mathrm{M}$ acetate buffer $(\mathrm{pH} 3.5)$ 에 녹인 $\mathrm{HA}(12 \mathrm{mg} / \mathrm{ml})$ 를 첨가하여 다시 40 분간 배 양하여 $0.4 \mathrm{~N}$ potassiumtetraborate $0.1 \mathrm{ml}$ 및 $0.4 \mathrm{~N} \mathrm{NaOH}$ 용액을 $0.1 \mathrm{ml}$ 반응 혼합물에 첨가하여 3 분 동안 수욕상에서 가열한 후 완전히 냉각시켰다. 냉각 시킨 반응물에 발색제로 $\mathrm{DMAB}$ 시약 $3 \mathrm{ml}$ 을 가하여 $37^{\circ} \mathrm{C}$ 에서 20 분간 배양한 다음 585 $\mathrm{nm}$ 에서 흡광도를 측정하여 저해활성을 산출하였다.

$$
\text { 저해율 }(\%)=\left(1-\frac{\text { 시료첨가군의 흡광도 }}{\text { 무첨가군의 흡광도 }}\right) \times 100
$$

\section{Lipoxygenase 저해활성 측정}

Lipoxygenase 저해활성 측정은 Tappel 등[28]의 방법을 변 형하여 실험하였다. 즉 반응구는 $0.1 \mathrm{M}$ tris-buffer $(\mathrm{pH}$ 8.5) $2 \mathrm{ml}$ 와 시료용액 $0.02 \mathrm{ml}$ 를 첨가하고 lipoxygenase (500 $\mathrm{U} / \mathrm{ml}) 0.03 \mathrm{ml}$ 를 첨가하여 $18^{\circ} \mathrm{C}$ 에서 5 분간 배양한 다음 110 $\mu \mathrm{M}$ linolenic acid $0.05 \mathrm{ml}$ 를 첨가하여 20분간 반응시켜 254 $\mathrm{nm}$ 에서 측정하였다.

$$
\text { 저해율 }(\%)=\left(1-\frac{\text { 시료첨가군의 흡광도 }}{\text { 무첨가군의 흡광도 }}\right) \times 100
$$




\section{Nitric oxide 저해활성 측정}

Nitric oxide (NO) 측정은 cell의 supernatant에서의 nitric oxide (NO)의 량을 nitrite and nitrate로서 측정을 하였다[11]. Nitrite에 대한 nitrate로 환원된 후의 안전한 형태인 griess reagent (Sigma, USA)를 사용하였으며, 6 well plate에 $2 \times 10^{6}$ 개 의 cell을 confluence가 $80 \%$ 일 때, PBS로 2 번 washing한 후에 무혈청 배지를 사용하여 12시간 이상 배양시킨 후에 lipopolysaccharide (LPS) $10 \mathrm{\mu g} / \mathrm{ml}$ 을 control군을 뺀 모든 well 에 다 넣어서 자극시켰다. 2 시간 후에 시료를 농도별로 처리하 여 실험하였다. NO 생성량은 24시간 후에 supernatant를 모아 griess reagent로 10 분간 반응시킨 후에 $540 \mathrm{~nm}$ 에서 흡광도로 측정하였다. LPS만 첨가한 군에서 생성된 $\mathrm{NO}$ 의 양을 $100 \%$ 로 하여 시료가 첨가된 경우에 측정된 흡광도를 환산하여 표기하 였다.

Nitric oxide $(\%)=\left(1-\frac{\text { 시료첨가군의 흡광도 }}{\text { 무첨가군의 흡광도 }}\right) \times 100$

\section{MTT assay에 의한 세포 생존율 측정}

세포 생존율 측정은 Carmichael 등의 방법[7]에 따라 측정 하였다. 세포주 macrophage (Raw 264.7) cell을 96 well plate 에 $5 \times 10^{3}$ cells/well이 되게 $0.2 \mathrm{ml}$ 분주하여 $37^{\circ} \mathrm{C}, 5 \% \mathrm{CO}_{2}$ incubator에서 24시간 배양한 후, 무혈청배지 $0.18 \mathrm{ml}$ 에 시료 를 농도 별로 조제하여 $0.02 \mathrm{ml}$ 첨가한 후 대조군은 시료와 동량의 무혈청 배지를 첨가하여 동일한 조건으로 배양하였다. 여기에 $2.5 \mathrm{mg} / \mathrm{ml}$ 농도로 제조한 MTT 용액 $0.02 \mathrm{ml}$ 를 첨가하 여 3시간 배양한 후 배양액을 제거하고 각 well당 DMSO 0.1 $\mathrm{ml}$ 를 가하여 실온에서 30 분간 반응 시킨 뒤 ELISA reader로 $540 \mathrm{~nm}$ 에서 흡광도를 측정하였다. 세포 생존율 측정은 시료용 액의 첨가군와 무첨가군의 흡광도 감소율로 나타내었다.

$$
\text { 세포 생존율 }(\%)=\left(1-\frac{\text { 시료첨가군의 흡광도 }}{\text { 무첨가군의 흡광도 }}\right) \times 100
$$

\section{Western blot을 통한 iNOS, COX-2 단백질의 발현 측정}

염증 관련 단백질 발현을 측정하기 위하여 Raw 264.7 세포 를 $10 \% \mathrm{FBS}$ contained DMEM으로 희석하여 $1 \mathrm{ml}$ 당 $5 \times 10^{4}$ 가 되도록 한 후 $100 \mathrm{~mm}$ dish에 넣고 $37^{\circ} \mathrm{C}, 5 \% \mathrm{CO}_{2}$ incubator에 서 24시간을 배양하였다. 그 다음 dish를 PBS로 2회 세척하고 serum excluded DMEM을 넣은 후 검색 시료와 LPS $(1 \mu \mathrm{l} / \mathrm{ml})$ 을 차례로 처리하여 10분, 16 시간을 배양하였다. 배양 후 cold $\mathrm{PBS}$ 로 2회 세척한 후 끓고 있는 cell lysis buffer를 넣고 scraper로 긁어 모으고 이를 $100^{\circ} \mathrm{C}$ 에 5 분간 두었다. 식힌 후 $-4^{\circ} \mathrm{C}$ 에 서 보관하였으며, 사용 직전에 $37^{\circ} \mathrm{C}$ 에서 녹여 단백질 정량 및 전기영동에 이용하였다. 단백질은 bradford법을 통하여 정량 하였으며, $20 \mu \mathrm{g}$ 의 샘플을 $10 \%$ SDS-polyacrylamide gel에 100 $\mathrm{V}$ 로 2시간 동안 전기영동 하였다. 원하는 부위의 gel을 잘라
3시간 동안 PVDF membrane으로 옮긴 후 PBST로 2회 세척하 고 blocking buffer에 넣어 상온에서 1시간 동안 배양하였다. 그 다음 TBST로 10 분간 3회씩 세척한 다음 primary antibody 를 염증 관련 단백질인 iNOS (BD Bionsience1:1,000), COX-2 (Cayman1:1,000)와 house keeping gene인 GAPDH (santacruz1:1,000)가 되도록 3\% skimmed milk in TBST로 희 석하여 membrane과 함께 상온에서 4 5시간 배양하였다. Membrane을 PBST로 10분간 3회씩 세척한 후 HRP-conjugated secondary antibody (santacruz1)을 1:1,000으로 희석 하여 membrane과 함께 상온에서 50 분간 배양하였다. 이를 TBST로 10분간 3회 세척한 후 ECL western blotting detection reagents를 처리하여 생성된 luminescence를 X-ray film에 감 광해 확인하였다.

\section{결과 및 고찰}

\section{카카오 분획물의 총 폴리페놀 함량 측정 결과}

카카오의 용매별 분획물에 존재하는 총 폴리페놀 함량을 tannic acid를 기준물질로 하여 카카오 분획물의 폴리페놀 함 량을 측정한 결과 Table 1과 같이 나타내었다. 카카오의 클로 로포름층은 $9.30 \pm 1.01 \mathrm{mg} \quad \mathrm{TAE} / \mathrm{g}$, 에틸아세테이트층은 $38.8 \pm 2.08 \mathrm{mg} \mathrm{TAE} / \mathrm{g}$, 부탄올층은 $23.3 \pm 1.41 \mathrm{mg} \mathrm{TAE} / \mathrm{g}$, 물층 은 $19.5 \pm 2.02 \mathrm{mg} \mathrm{TAE} / \mathrm{g}$ 으로 나타났다. 특히 에틸아세테이트 층의 폴리페놀 함량이 가장 높게 나타났다. 이는 Lee 등[20]의 국내산 약용식물 중의 총 폴리페놀 함량을 분석한 결과, 제비 꽃의 폴리페놀 함량은 $\mathrm{MeOH}, \mathrm{EtOH}$, acetone, water 추출물에 서 각각 $34.49 \pm 1.11,29.45 \pm 3.05,17.80 \pm 3.37,30.71 \pm 1.28 \mathrm{mg}$ $\mathrm{GAE} / \mathrm{g}$ 이며, Kwon 등[19]의 산겨릅나무 추출물에서 열수, $\mathrm{EtOH}, \mathrm{CHCl}_{3}$ 층, $\mathrm{EtOAc}$ 층 $\mathrm{BuOH}$ 층, aqueous층에서 각각 $1.5 \pm 0.19,2.3 \pm 0.17,2.3 \pm 0.22,5.1 \pm 0.21,3.0 \pm 0.22,0.6 \pm 0.09 \mathrm{mg}$ $\mathrm{TAE} / \mathrm{g}$ 의 폴리페놀 함량이 나타났다는 보고가 있다. 이들 결 과와 비교해 볼 때 카카오에도 상당한 폴리페놀이 함유됨을 확인할 수 있었다.

\section{카카오 분획물의 전자공여능 확인}

카카오 분획물을 이용한 전자공여능 측정 결과 Fig. 1 과 같

Table 1. The contents of total polyphenols of solvent fractions from Theobroma cacao L.

\begin{tabular}{cc}
\hline Solvent for extraction & $\begin{array}{c}\text { Contents of polyphenols } \\
(\mathrm{mg} \mathrm{TAE} / \mathrm{g})^{1)}\end{array}$ \\
\hline $\mathrm{CHCl}_{3}$ layer & $9.30 \pm 1.01^{2)}$ \\
EtOAc layer & $38.8 \pm 2.08$ \\
$\mathrm{n}-\mathrm{BuOH}$ layer & $23.3 \pm 1.41$ \\
$\mathrm{H} 2 \mathrm{O}$ layer & $19.5 \pm 2.02$ \\
\hline
\end{tabular}

\footnotetext{
${ }^{1)}$ TAE standards for tannic acid equivalents

${ }^{2)}$ Results are mean \pm S.D of triplicate data.
} 


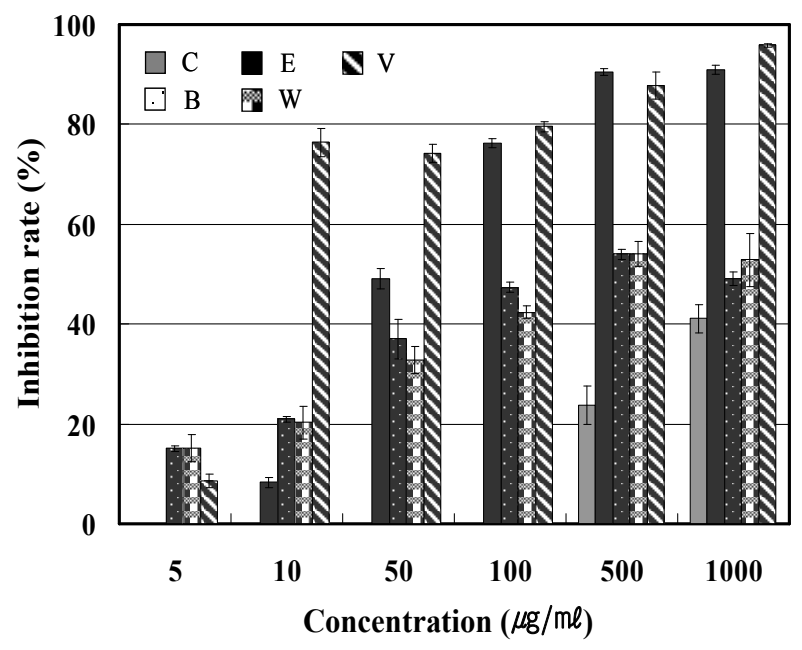

Fig. 1. Electron donating ability of solvent fractioning an extracts from Theobroma cacao L. C: Chloroform layer of acetone extracted T. cacao L., E: Ethyl acetate layer of acetone extracted T. cacao L., B: Butanol layer of acetone extracted T. cacao L., W: Water layer of acetone extracted $T$. cacao L., V: vitamin C. Results are means \pm S.D. of triplicate data.

이 나타내었다. $100 \mu \mathrm{g} / \mathrm{ml}$ 에서 에틸아세테이트 분획물이 $76.2 \%$, 부탄올 분획물이 $53.9 \%$, 물 분획물이 $42.4 \%$ 를 나타내 었으며, 대조군인 Vit.C에서는 $79.5 \%$ 의 전자공여능을 나타내 었다. 각 분획물들의 $\mathrm{IC}_{50}$ 값은 에틸아세테이트 분획물은 58.19 $\mu \mathrm{g} / \mathrm{ml}$, 부탄올 분획물은 $284.39 \mu \mathrm{g} / \mathrm{ml}$, 물 분획물은 290.13 $\mu \mathrm{g} / \mathrm{ml}$ 로 측정되었다. 특히 에틸아세테이트 분획물이 $500 \mu \mathrm{g} /$ $\mathrm{ml}$ 에서 $90 \%$ 이상의 활성을 나타내었으며, 부탄올과 물 분획 물의 경우 $500 \mu \mathrm{g} / \mathrm{ml}$ 에서 $50 \%$ 이상의 활성을 나타내었다. 또 한 모든 분획물에서 농도 증가에 따라 활성이 증가함을 확인 할 수 있었다. 이는 $\mathrm{Kim}$ 등[18]의 백단향의 전자공여능 측정에 서 메탄올 추출물의 $\mathrm{IC}_{50}$ 은 $35.8 \mathrm{\mu g} / \mathrm{ml}$ 의 저해능을 나타냈으 며, 에탄올, 열수 추출에서 $\mathrm{IC}_{50}$ 은 각각 $47.2 \mu \mathrm{g} / \mathrm{ml}, 57.8 \mu \mathrm{g} / \mathrm{ml}$ 의 저해능을 나타내었다. 또한 Choi 등[9]의 와송 추출물에서 9월에 채취한 와송 메탄올 추출물의 전자공여능은 $1,000 \mu$ $\mathrm{g} / \mathrm{ml}$ 의 농도에서 각각 $88.3 \%$ 의 효과를 나타내었으며, 9 월에 채취한 와송 열수 추출물의 전자공여능은 $1,000 \mu \mathrm{gg} / \mathrm{ml}$ 의 농도 에서 각각 $60.6 \%$ 의 효과를 나타내었다. 또한 Lee 등[22]의 땅 콩 품종간 항산화 활성에서 새들땅콩, 대광땅콩, 대풍땅콩이 각각 $90.4 \%, 90.2 \%, 90.3 \%$ 의 전자공여능이 나타났으며, $\mathrm{Im}$ 등 [13]의 오가피에서 $10,20,40,60 \%$ 에탄올 분획물의 $\mathrm{IC}_{50}$ 이 각 각 $81.534 \mu \mathrm{g} / \mathrm{ml}, 1.748 \mu \mathrm{g} / \mathrm{ml}, 11.487 \mu \mathrm{g} / \mathrm{ml}, 21.960 \mu \mathrm{g} / \mathrm{ml}$ 의 전자공여능을 나타내었다.

카카오 분획물의 superoxide anion radical 소거능 확인

카카오 분획물의 superoxide anion radical 소거능은 Fig. 2와 같이 나타내었다. 각 분획물의 superoxide anion radical

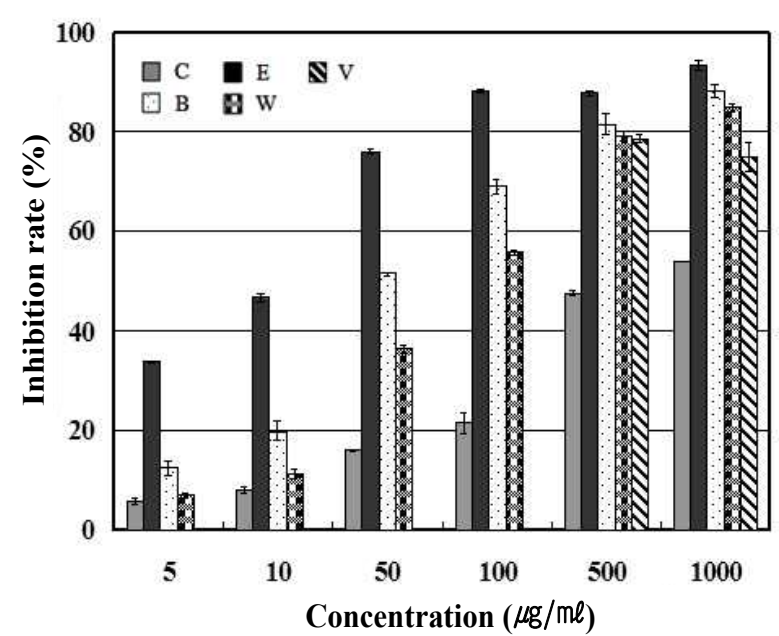

Fig. 2. Superoxide anion radical scavenging activity of solvent fractioning an extracts from Theobroma cacao L. C: Chloroform layer of acetone extracted T. cacao L., E: Ethyl acetate layer of acetone extracted T. cacao L., B: Butanol layer of acetone extracted T. cacao L., W: Water layer of acetone extracted T. cacao L., V: vitamin C. Results are means \pm S.D. of triplicate data.

소거능은 클로로포름 분획물이 $1,000 \mu \mathrm{g} / \mathrm{ml}$ 에서 $53.9 \%$ 의 소 거능을 보였고, 에틸아세테이트 분획물이 $50 \mu \mathrm{g} / \mathrm{ml}$ 에서 $76.09 \%$, 부탄올 분획물이 $50 \mu \mathrm{g} / \mathrm{ml}$ 에서 $51.4 \%$, 물 분획물이 $100 \mathrm{\mu g} / \mathrm{ml}$ 에서 $55.7 \%$ 를 나타내었으며, 대조군인 Vit.C에서는 $500 \mu \mathrm{g} / \mathrm{ml}$ 에서 $78.7 \%$ 의 소거능을 나타내었다. 각 분획물들의 $\mathrm{IC}_{50}$ 값은 클로로포름이 $726.36 \mu \mathrm{g} / \mathrm{ml}$, 에틸아세테이트 분획물 은 $21.7 \mathrm{\mu g} / \mathrm{ml}$, 부탄올 분획물은 $36.8 \mathrm{\mu g} / \mathrm{ml}$, 물 분획물은 79.1 $\mu \mathrm{g} / \mathrm{ml}$ 로 측정되었다. 카카오 분획물 중 에틸아세테이트 분획 물이 가장 강한 소거능을 나타내었다. 또한 분획물의 농도 증 가에 따라 활성이 증가함을 확인할 수 있었으며, 에틸아세데 이트 분획물의 경우 $500 \mathrm{\mu g} / \mathrm{ml}$ 에서 $90 \%$ 의 활성을, 부탄올 분 획물의 경우 $500 \mu \mathrm{g} / \mathrm{ml}$ 에서 $80 \%$ 의 활성을, 물 분획물의 경우 $500 \mu \mathrm{g} / \mathrm{ml}$ 에서 $80 \%$ 의 활성을 나타내어 $500 \mu \mathrm{g} / \mathrm{ml}$ 에서 가장 활성 증가가 높음을 확인할 수 있었으며, superoxide anion radical 소거능의 경우 대조군인 Vit.C 보다 활성이 우수함을 확인할 수 있었다.

\section{카카오 분획물의 $\mathrm{Fe}^{2+}, \mathrm{Cu}^{2+}$ 의 첨가에 따른 지방산패 억} 제능 확인

2-thiobarbuturic acid reactive substance (TBARS)는 불포 화 지방산이 자동 산화하는 과정 중 지방산화의 2차 산물인 malonaldehyde (MA)가 발생하며, 이는 높은 반응성을 가지 고 있다. 이러한 malonaldehyde (MA)는 2-thiobarbuturic acid (TBA)시약과 반응하는 주된 물질이며, $531 \mathrm{~nm}$ 에서 형광 을 갖는 물질을 만든다. 생체 내에서 세포막에 존재하는 인지 질 및 당지질과 혈관에 존재하는 지질은 산소와 결합하여 과 
산화물을 만들고 이들의 연속반응에 의하여 alcohol류, aldehyde류, ketone류 등을 생성하여 생체 내에서 DNA를 손상시 켜 암을 유발하기도 하며, 세포의 노화와도 관련이 있는 것으 로 알려져 있다[10]. 이러한 지방산패의 억제 효과를 측정하기 위해 산화촉진제인 $\mathrm{Fe}^{2+}, \mathrm{Cu}^{2+}$ 이온첨가에 따른 카카오 분획물 들의 지방산패 억제능을 측정한 결과 Fig. 3,4 와 같이 나타내 었다. $\mathrm{Fe}^{2+}$ 를 첨가한 군에서는 vitamin C의 경우 $50 \mu \mathrm{g} / \mathrm{ml}$ 에 서 $57 \%$ 의 저해능이 나타난 반면, 에틸아세테이트층은 $50 \mathrm{\mu g} /$ $\mathrm{ml}$ 에서 $64 \%$ 의 억제능을 나타내어 vitamin $\mathrm{C}$ 보다 높은 활성을 나타내었고, 클로로포름, 에틸아세테이트, 부탄올 분획물 모 두 $100 \mathrm{\mu g} / \mathrm{ml}$ 에서 $50 \%$ 이상의 저해능이 확인되었다. $\mathrm{Cu}^{2+}$ 를 첨가한 군에서 vitamin C의 경우 $1,000 \mathrm{\mu g} / \mathrm{ml}$ 에서 $52 \%$ 의 억 제능을 나타낸 반면, 에틸아세테이트 분획물, 물 분획물의 경 우 $1,000 \mu \mathrm{g} / \mathrm{ml}$ 에서 $60 \%$ 의 저해능을 나타내었다. $\mathrm{IC}_{50}$ 값으로 $\mathrm{Fe}^{2+}$ 를 첨가한 군에서는 클로로포름, 에틸아세테이트, 부탄올, 물 분획물의 $\mathrm{IC}_{50}$ 값은 각각 $99.78 \mu \mathrm{gg} / \mathrm{ml}, 27.59 \mu \mathrm{gg} / \mathrm{ml}, 68.13$ $\mathrm{\mu g} / \mathrm{ml}, 647.84 \mathrm{\mu g} / \mathrm{ml}$ 로 나타났고, vitamin C의 $\mathrm{IC}_{50}$ 값은 28.02 $\mu \mathrm{g} / \mathrm{ml}$ 으로 나타났으며, $\mathrm{Cu}^{2+}$ 를 첨가한 군에서는 에틸아세테 이트 분획물의 $\mathrm{IC}_{50}$ 값은 $833.3 \mu \mathrm{g} / \mathrm{ml}$ 으로 나타난 반면, vita$\operatorname{min~C}$ 은 $752.5 \mu \mathrm{g} / \mathrm{ml}$ 로 나타났다. 상대적으로 $\mathrm{Cu}^{2+}$ 보다 $\mathrm{Fe}^{2+}$ 첨가의 지방산패 억제능이 더 높음을 확인하였으며, 특히 에 틸아세테이트 분획물의 $\mathrm{Fe}^{2+}$ 이온 첨가에 따른 지방산패 억제 능이 가장 탁월함을 확인할 수 있었다.

\section{카카오 분획물의 hyaluronidase 저해활성 확인}

히아루론산(hyaluronic acid, $\mathrm{HA}$ )은 결합조직의 세포 외 기

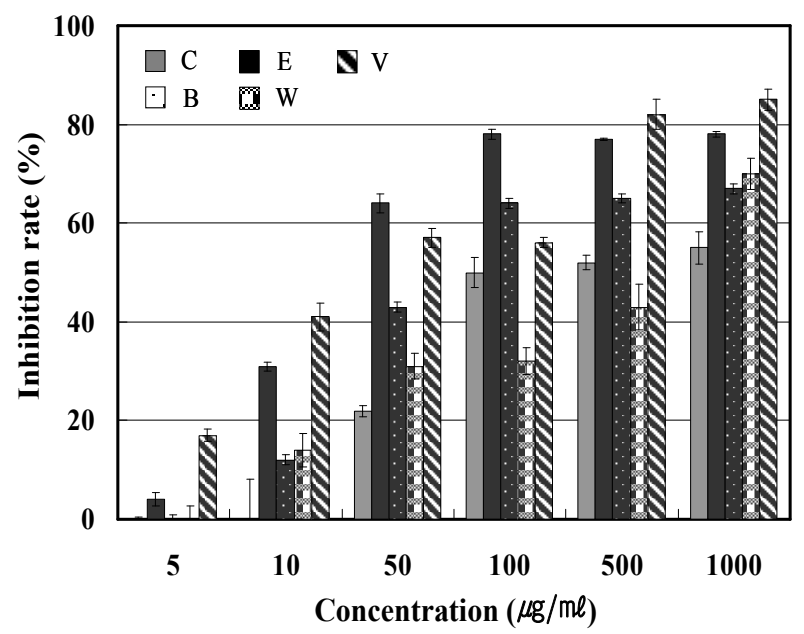

Fig. 3. $\mathrm{Fe}^{2+}$ ion on lipid oxidation in oil emulsion of solvent fractioning an extracts from Theobroma cacao L. C: Chloroform layer of acetone extracted $T$. cacao L., E: Ethyl acetate layer of acetone extracted $T$. cacao L., B: Butanol layer of acetone extracted T. cacao L., W: Water layer of acetone extracted $T$. cacao L., V: vitamin C. Results are means \pm S.D. of triplicate data.
질에 존재하는 다당체이며, 진피에 존재한다. 고분자 $\mathrm{HA}$ 는 대식세포의 식작용을 억제하여 염증반응을 조절하는 작용을 하고 있으며, hyaluronidase는 고분자 $\mathrm{HA}$ 를 분해하여 저분자 $\mathrm{HA}$ 로 변형하는 효소이다[24]. 저분자 $\mathrm{HA}$ 는 류마티스 관절염 들 염증성 질환 환자에게서 고농도로 발견된다. 따라서 항염 증 치료제의 연구에서 hyaluronidase 저해제의 개발은 중요한 연구목표이다[14]. 특히 아토피성 피부염 치료제 등의 연구에 서 hyaluronidase 저해제는 관심을 끌고 있다. 카카오 분획물 이 HA를 분해하는 HAase를 저해할 수 있는지 알아보고자 다양한 농도에서 효소 저해 효과를 측정하여 Fig. 5와 같이 나타내었다. 카카오 클로로포름 분획물의 경우 $500 \mu \mathrm{g} / \mathrm{ml}$ 에 서 $61.37 \%$, 에틸아세테이트 분획물의 경우 $500 \mu \mathrm{g} / \mathrm{ml}$ 에서 $54.54 \%$, 부탄올 분획물의 경우 $100 \mathrm{\mu g} / \mathrm{ml}$ 에서 $53.04 \%$, 물 분 획물의 경우 $500 \mathrm{\mu g} / \mathrm{ml}$ 에서 $56.86 \%$ 의 저해 효과가 나타났고, $\mathrm{IC}_{50}$ 값은 각각 $281.43 \mu \mathrm{g} / \mathrm{ml}, 280.46 \mu \mathrm{g} / \mathrm{ml}, 86.0 \mu \mathrm{gg} / \mathrm{ml}, 270.73$ $\mu \mathrm{g} / \mathrm{ml}$ 으로 나타났다. 대조군인 vitamin C의 경우 $1,000 \mu \mathrm{g} /$ $\mathrm{ml}$ 에서 $19.72 \%$ 의 저해능이 나타났다. 또한 분획물의 hyaluronidase 저해활성의 경우 $100 \mathrm{\mu g} / \mathrm{ml}$ 의 농도까지만 증 가하는 경향을 보이다가 그 이후의 농도에서는 부탄올을 제외 한 나머지 분획물에서는 활성의 변화를 확인할 수 없었다. 이 는 농도가 증가할수록 효소와 반응한 분획물의 색이 짙어져 흡광도 수치가 높아지면서 정확한 값을 측정하기 어려웠으며, 이후 세포를 통한 메커니즘 분석에서 정확한 효능을 확인해야 할 것으로 사료된다. 타 논문과 비교한 결과 $\mathrm{Bu}$ 등[5]의 감태에 서 분리한 6 개의 탄닌 화합물 $\mathrm{IC}_{50}$ 값에서 eckol $(36.1 \mathrm{\mu g} / \mathrm{ml})$, eckstolonol $(77.9 \mu \mathrm{g} / \mathrm{ml})$, triphlorethol $(28.9 \mu \mathrm{g} / \mathrm{ml})$, dieckol

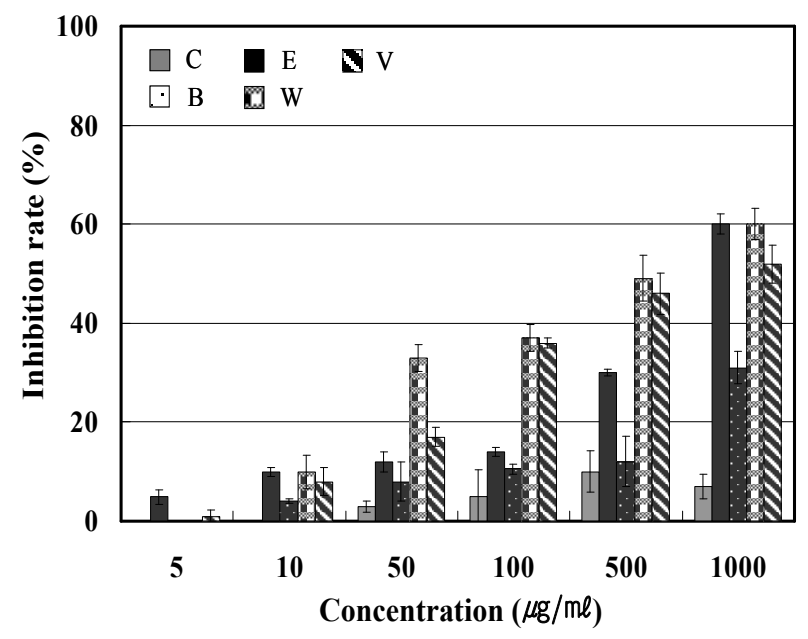

Fig. 4. $\mathrm{Cu}^{2+}$ ion on lipid oxidation in oil emulsion of solvent fractioning an extracts from Theobroma cacao L. C: Chloroform layer of acetone extracted $T$. cacao L., E: Ethyl acetate layer of acetone extracted $T$. cacao L., B: Butanol layer of acetone extracted T. cacao L., W: Water layer of acetone extracted $T$. cacao L., V: vitamin C. Results are means \pm S.D. of triplicate data. 


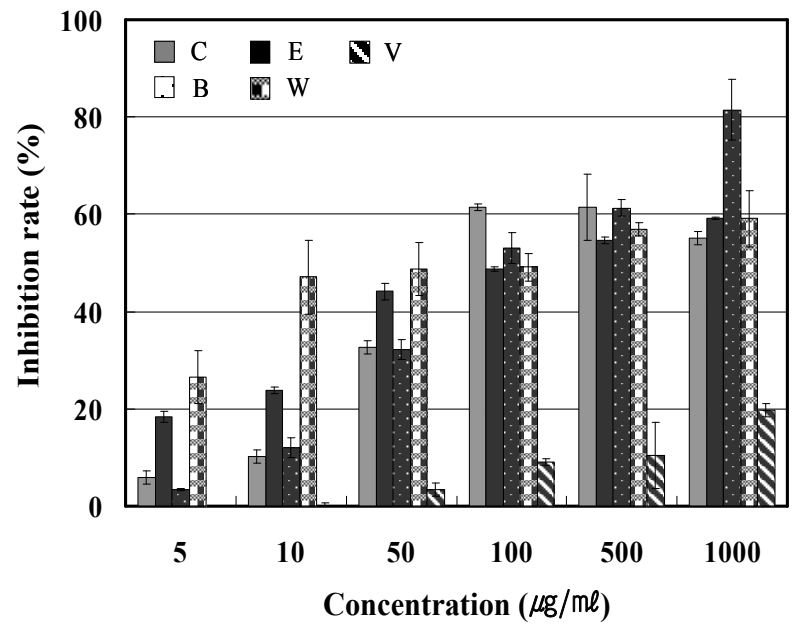

Fig. 5. Hyaluronidase inhibition rate of solvent fractioning an extracts from Theobroma cacao L. C: Chloroform layer of acetone extracted T. cacao L., E: Ethyl acetate layer of acetone extracted T. cacao L., B: Butanol layer of acetone extracted $T$. cacao L., W: Water layer of acetone extracted T. cacao L., V: vitamin. Results are means \pm S.D. of triplicate data.

(14.9 $\mu \mathrm{g} / \mathrm{ml})$, phlorofucofuroeckol A $(63.3 \mu \mathrm{g} / \mathrm{ml})$, ursolic $\operatorname{acid}(12.3 \mu \mathrm{g} / \mathrm{ml})$ 을 나타내었고, Cha 등[8]의 석창포 분획물 중 에틸아세테이트 분획물의 $\mathrm{IC}_{50}$ 값이 $91.1 \mu \mathrm{g} / \mathrm{ml}$ 을 비교 시 유의한 효과를 나타냄을 확인하였다.

\section{카카오 분획물의 lipoxygenase 저해활성 확인}

카카오 분획물의 lipoxygenase 저해활성 실험을 linolenic acid를 기질로 하여 soybean lipoxygenase에 의한 과산화 반 응을 조사한 결과 Fig. 6과 같이 나타났다. 클로로포름 분획물 의 경우 $100 \mu \mathrm{g} / \mathrm{ml}$ 의 농도에서 $80 \%$ 이상의 저해율을 나타내 었으며, 에틸아세테이트 분획물의 경우 $100 \mu \mathrm{g} / \mathrm{ml}$ 에서 $90 \%$ 이상의 저해활성을 나타내었다. 이는 대조군인 카테킨의 100 $\mu \mathrm{g} / \mathrm{ml}$ 의 농도에서 $75 \%$ 의 저해율과 비교할 때 클로포름 및 에틸아세테이트 분획물의 활성이 우수함을 확인할 수 있었다. 또한 분획물의 농도가 증가할수록 활성이 증가하는 경향을 나타내었다. 또한 lipoxygenase를 $50 \%$ 저해하는 농도 $\left(\mathrm{IC}_{50}\right)$ 를 측정한 결과 에틸아세테이트 분획물은 $9.1 \mu \mathrm{g} / \mathrm{ml}$, 클로로포름 분획물은 $309 \mu \mathrm{g} / \mathrm{ml}$, 부탄올 분획물은 $554.3 \mu \mathrm{g} / \mathrm{ml}$, 물 분획 물은 $728.8 \mu \mathrm{g} / \mathrm{ml}$ 을 나타내어 에틸아세테이트 분획물의 $\mathrm{IC}_{50}$ 값이 가장 낮게 나타났다. 이는 Choi 등[9]의 들깨박으로부터 분리된 플라보노이드에서 lipoxygenase의 $\mathrm{IC}_{50}$ 을 측정한 결과 apigenin이 $19.14 \pm 0.15 \mu \mathrm{M}$, luteolin이 $9.09 \pm 0.08 \mu \mathrm{M}$, quercetin은 $12.92 \pm 0.11 \mu \mathrm{M}$, kaempferol이 $30.14 \pm 0.21$ 를 나타내어 카 카오 에틸아세테이트 분획물의 lipoxygenase 저해능이 우수 함을 확인할 수 있었다.



Fig. 6. Lipoxygenase inhibition rate of solvent fractioning an extracts from Theobroma cacao L. C: Chloroform layer of acetone extracted T. cacao L., E: Ethyl acetate layer of acetone extracted T. cacao L., B: Butanol layer of acetone extracted T. cacao L., W: Water layer of acetone extracted T. cacao L., CTC: Catechin, Results are means \pm S.D. of triplicate data.

카카오 분획물에 의한 대식세포(RAW 264.7)의 독성 확인

카카오 분획물에 의한 macrophage 세포의 독성을 MTT assay에 의해 확인한 결과 Fig. 7과 같이 나타내었다. 즉 카카오 분획물이 lipopolysaccharide (LPS)로 유도된 nitric oxide의 생성을 감소시킨 것인지, 카카오 분획물의 세포독성으로 인한 cell population의 저하에서 기인하는 것인지를 측정한 결과, 카카오 부탄올 분획물을 제외하고 모두 $500 \mu \mathrm{g} / \mathrm{ml}$ 까지 $20 \%$ 이하의 세포 독성을 나타내었으며, 부탄올 분획물은 vitamin $\mathrm{C}$ 와 비교 시 $50 \mu \mathrm{g} / \mathrm{ml}$ 부터 농도 의존적으로 높은 세포 독성율 을 보였고, $50 \mu \mathrm{g} / \mathrm{ml}$ 에서 $20 \%$ 이상의 독성을 나타내어 가장 높은 세포 독성을 나타내었다.

\section{카카오 분획물의 nitric oxide 저해활성 확인}

체내 염증과정에서는 과량의 nitric oxide (NO) 및 prostaglandin $\mathrm{E}_{2} \quad\left(\mathrm{PGE}_{2}\right)$ 등의 염증인자가 유도형 $\mathrm{NO}$ synthase (iNOS) 및 cyclooxygenase (COX)-2에 의해 형성된다. 이 중 $\mathrm{NO}$ 는 체내 방어기능, 신호전달기능, 신경독성, 혈관 확장 등 의 다양한 생리기능을 가지고 있다[25,26]. 일반적으로 $\mathrm{NO}$ 의 형성은 박테리아를 죽이거나 종양을 제거시키는 중요한 역할 을 하지만 병리학적인 원인에 의한 과도한 $\mathrm{NO}$ 의 형성은 염증 을 유발시키게 되며, 조직의 손상, 유전자 변이 및 신경 손상 등을 유발 한다[23,29]. RAW 264.7 cell의 NO 생성억제 정도를 측정하기 위하여 카카오 분획물을 농도별로 세포에 처리하여 생성되는 NO량을 측정한 결과 Fig. 8과 같이 나타내었다. LPS 를 첨가하지 않은 군에서는 $16 \sim 18 \%$ 의 $\mathrm{NO}$ 를 생성하였고, 


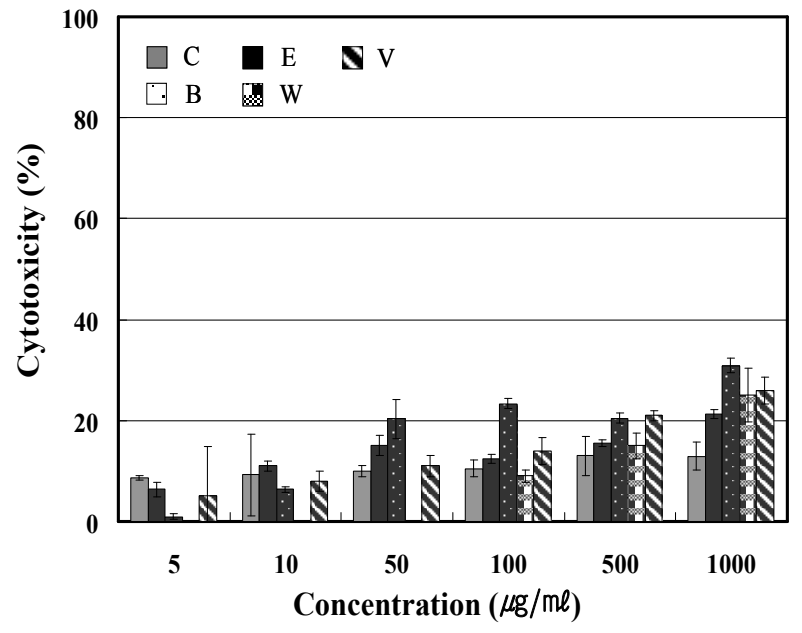

Fig. 7. Optical of cell concentration on macrophage cell (RAW 264.7). C: Chloroform layer of acetone extracted T. cacao L., E: Ethyl acetate layer of acetone extracted T. cacao L., B: Butanol layer of acetone extracted T. cacao L., W: Water layer of acetone extracted T. cacao L., V: vitamin, Results are means \pm S.D. of triplicate data.

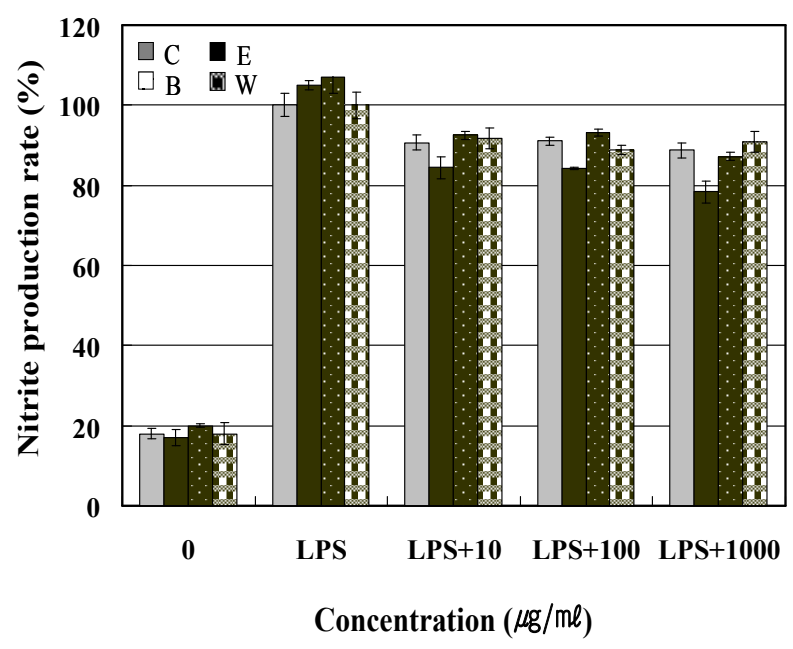

Fig. 8. Effects of solvent fractioning an extracts from Theobroma cacao $\mathrm{L}$. on the production of nitric oxide in macrophage cell (RAW 264.7). C: Chloroform layer of acetone extracted T. cacao L., E: Ethyl acetate layer of acetone extracted T. cacao L., B: Butanol layer of acetone extracted T. cacao L., W: Water layer of acetone extracted T. cacao L., Results are means \pm S.D. of triplicate data.

LPS와 카카오 분획물을 첨가한 군에서는 에틸아세테이트 분 획물이 $\mathrm{NO}$ 의 생성량을 가장 많이 억제하였다. 즉, 에틸아세테 이트 분획물은 농도 의존적으로 $\mathrm{NO}$ 의 생성을 억제함을 확인 할 수 있었으며 $1,000 \mu \mathrm{g} / \mathrm{ml}$ 에서 $\mathrm{NO}$ 의 생성을 $78.34 \%$ 를 억제 하였다. 이는 Byun 등[6]의 현삼 메탄올 추출물과 Kim 등[17] 의 상황 $\mathrm{H}_{2} \mathrm{O}$ 추출물의 LPS로 유도된 Raw cell의 $\mathrm{NO}$ 생성 억제능에 미치는 결과와 비교하여 보면 카카오 분획물 중 에
틸아세테이트 분획물이 NO 생성 억제능이 가장 우수하다는 것을 확인할 수 있었다.

\section{카카오 분획물의 iNOS, COX-2 단백질의 발현 측정 결과}

염증과정 중에 많은 양의 염증유도 사이토카인(pro-inflammatory cytokines), nitric oxide (NO) 그리고 prostaglandin E2 (PGE2)가 inducible nitric oxide synthase (iNOS) 와 cyclooxygenase-2 (COX-2)에 의해 생성된다[17]. 특히, 자 극에 유도된 $\mathrm{iNOS}$ 인 경우 오랜 기간 동안 다량의 $\mathrm{NO}$ 를 생성 하게 되고, 생성된 $\mathrm{NO}$ 는 guanylyl cyclase의 활성과 동시에 주위 조직에 세포독성을 나타내는 것이 특징이다. 즉 LPS로 유도 되어진 RAW 264.7 cell에서 iNOS의 protein level의 감소 에 의해 항염증 효과를 기대할 수 있다. 카카오 에틸아세테이 트 분획물이 iNOS, COX-2 protein 발현 저해효과가 있는지 알아보기 위하여 RAW 264.7 cell에 LPS $(10 \mu \mathrm{g} / \mu \mathrm{l})$ 을 처리 하고 1 시간 뒤, 카카오 에틸아세테이트 분획물을 $100 \mu \mathrm{g} / \mathrm{ml}$ 로 처리 한 후 24 시간 배양한 후 iNOS, COX-2 protein의 발현 변화를 western blotting으로 확인하였다. 이때 세포의 여러 조건에서도 그 발현 정도의 차이가 거의 없는 house keeping gene인 GAPDH를 positive control로 사용하였으며, Fig. 9, 10 과 같이 LPS를 처리 하지 않은 normal 군에서는 iNOS, COX-2 protein 발현이 거의 나타나지 않았지만, LPS를 처리한 군에서는 산화적 스트레스가 유발되어 염증 반응을 매개하는 데 중요한 역할을 하는 것으로 알려진 iNOS protein 발현이 $130 \mathrm{kDa}$ 에서 상당 수준으로 나타났다. 대조적으로 카카오 에 틸아세테이트 분획물 $100 \mu \mathrm{g} / \mathrm{ml}$ 농도로 처리시 LPS에 의해

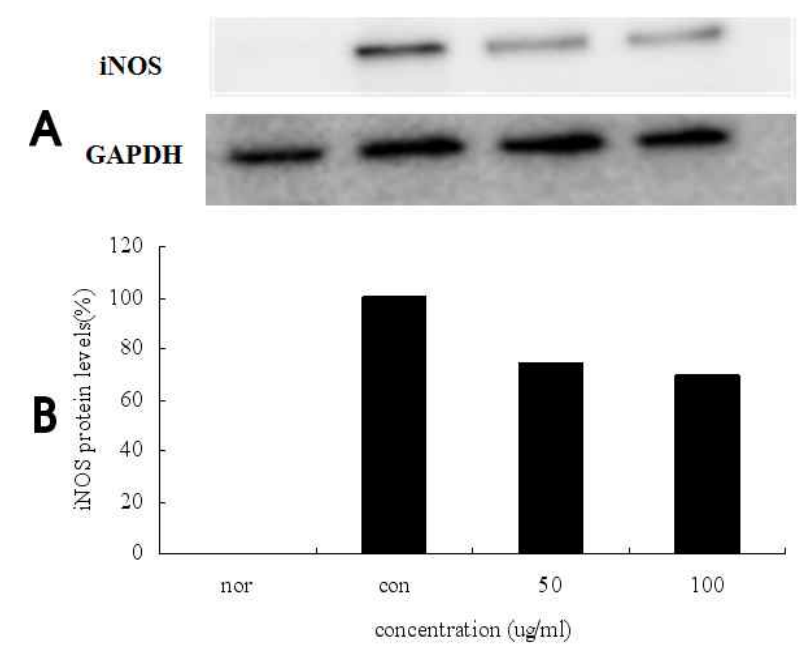

Fig. 9. iNOS protein expression rate of EtOAC layer isolated from Theobroma cacao L. 70\% acetone extract on macrophage cell (Raw264.7). A is representative lanes from western blots, it be showed induction of iNOS in RAW 264.7. B is density values of band from normal, it is effects of $T$. cacao L. EtOAc layer on iNOS protein expression in RAW 264.7 cell. 


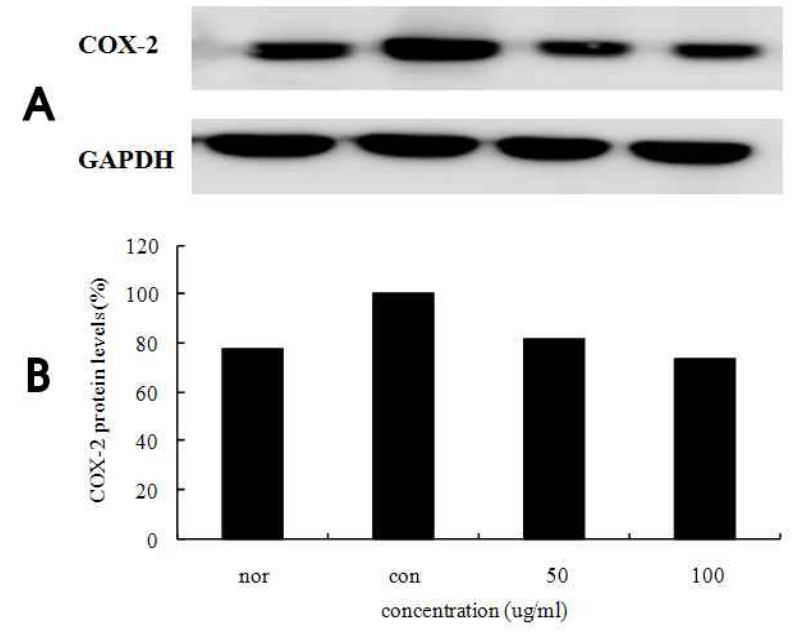

Fig. 10. COX-2 protein expression rate of EtOAC layer isolated from Theobroma cacao L. 70\% acetone extract on macrophage cell (Raw264.7). A is representative lanes from western blots, it be showed induction of COX-2 in RAW 264.7. B is density values of band from normal, it is effects of T. cacao L. EtOAc layer on COX-2 protein expression in RAW 264.7 cell.

증가된 iNOS, COX-2 protein 발현을 감소시켰다. 따라서 카카 오 에틸아세테이트 분획물이 LPS로 유발된 NO생성과 iNOS, COX-2 protein 발현을 억제함으로서 항염증 반응에 관여할 것으로 사료된다.

이상의 결과로부터 카카오 분획물의 항산화 및 항염증 효과 를 효소 및 세포에서 측정하여 활성을 확인할 수 있었으며, 전반적으로 에틸아세테아트 분획물의 활성이 우수하였다. 특 히 $100 \mu \mathrm{g} / \mathrm{ml}$ 이상의 농도에서 활성이 우수함을 확인할 수 있었다. 화장품에 첨가되는 소재는 제형의 안정성이 유지되는 한 독성이 없는 범위에서는 가능한 많은 양을 첨가하면 화장 품의 효능을 높인다. 카카오 분획물의 경우 화장품에 첨가 시 $0.01 \%(100 \mu \mathrm{g} / \mathrm{ml})$ 에서 $0.1 \%(1,000 \mu \mathrm{g} / \mathrm{ml})$ 정도의 양으로 활 성이 나타났으므로 적은 양으로도 화장품 소재로서의 가능성 이 있을 것으로 판단된다.

\section{References}

1. An, B. J. and Lee, J. T. 1998. Studies on the chemical structure of polyphenols isolated from medicinal plant. J. Life Resour. Ind 3, 48-58.

2. Association of Analytical Chemists. 1984. Offical methods of analysis of the AOAC. 14th eds. Washington (DC): Association of Analytical Chemists INC.

3. Blois, M. S. 1958. Antioxidant determination by the use of a stable free radical. Nature 26, 1199-1120.

4. Buege, J. A. and Aust, S. D. 1978. Microsomal lipid peroxidation. Meth. Enzymol. 52, 302-310.

5. Bu, H. J. 2006. Elastase and hyaluronidase inhibition activ- ities of phlorotannins isolated from Esklom'a cava Kor. J. Pharmacol. 37, 92-96.

6. Byun, S. H., Yang, C. H. and Kim, S. C. 2005. Inhibitory effect of Scrophulariae Radix extract on TNF-a, IL-3, IL-6 and nitric oxide production in lipopolysaccharide activated Raw 164.7 cells. Kor. J. Herbology 20, 7-16.

7. Carmichael, J., DeGraff, W. G., Gazdar, A. F., Minna, J. D. and Mitchell, J. B. 1987. Evaluation of a tetrazolium based semiautomated colorimetric assay: assessment of chemosensitivity testing. Cancer Res. 47, 936-942.

8. Cha, B. C. 2004. Glutathione S-transferase activity and hyaluronidase inhibitory effect of medicinal plants. Kor. J. Phamacogn. 35, 184-188.

9. Choi, S. Y., Chung, M. J. and Sung, N. J. 2008. Studies on the antioxidative ability of methanol and extracts from Orostachys japonicus A. Berger according to harvest times. Kor. J. Food Nutr. 21, 157-164.

10. Cojocaru, I. M., Cojocaru, M., Musuroi, C., Botezat, M., Lazar, L. and Druta, A. 2004. Lipid peroxidation and catalase in diabetes mellitus with and without ischemic stroke. Rom J. Intern. Med 42, 423-429.

11. Ding, A. H., Nathan, C. F. and Stuehr, D. J. 1988. Release of reactive nitrogen intermediates and reactive oxygen intermediates from mouse peritoneal macrophages. Comparison of activating cytokines and evidence for independent production. J. Immunol. 141, 2407-2412.

12. Fridovich, I. 1970. Quantitative aspects of the production of superoxide anion radical by milk xanthin oxidase. J. Bid. Chem 245, 4053-4057.

13. Im, K. Y., Kim, M. J., Jung, T. K. and Yoon, K. S. 2008. Antioxidant activity of partially purified extracts isolated from Acanthopanax sessiliflorum seeman. Kor. J. Biotechnol. Bioeng. 23, 329-334.

14. Kakegawa, H., Matsumoto, H". and Satoh, T. 1992. Inhibitory effects of some natural products on the activation of hyaluronidase and their anti-allergic action. Chem Pharm Bull. 40, 1439-1442.

15. Kim, J. D. 2004. The new technology development strategy of cosmeceuticals with use advanced materials resources. $J$. Soc. Cosmet. Scientists Korea 30, 427-438.

16. Kim, J. D. 2007. Development of cosmetics by using Cacao chocolate. Food Machinery 4, 3-10.

17. Kim, S. C., Jung, Y. S., Lee, J. R., Kim, Y. W., Byun, B. H., Kwon, T. K., Suh, S. I., Byun, S. H. and Kwon, Y. K. 2004. Inhibition effect of Phellinus Igniaril water extract on TNF-a, IL-3, IL-6 and nitric oxide production in lipopolysaccharide activated Raw 164.7 cells. Kor. J. Oriental Physiol. Pathol. 18, 880-886.

18. Kim, T. H. 2008. Antioxidative and biological activities of Santalum album extracts by extracting methods. Kor. J. Food Preserv. 15, 456-460.

19. Kwon, H. N., Park, J. R. and Jeon, J. R. 2008. Antioxidative and hepatoprotective effects of acertegmentosum M. extracts. J. Kor. Soc. Food Sci. Nutr. 37, 1389-1394.

20. Lee, B. B. and Park, S. R. 2008. Antioxidant activity and inhibition activity against a -glucosidase of Viola man- 
dshurica Extracts. J. Kor. Soc. Food Scii. Nutr. 37, 405-409.

21. Lee, K. W. 2007. Cancer chemo-preventive effect and physiological activities of Cacao chocolate. Food Machinery 4, 27-29.

22. Lee, S. E., Park, C. H., Bang, J. K., Seong, N. S. and Chung, T. Y. 2004. Comparison on antioxidant potential of several peanut varieties. J. Korean Sac. Food Sci. Nutr. 33, 941-945.

23. McCartney-Francis, N., Allen, J. B., Mizel, D. E., Albina, J. E., Xie, Q. W., Nathan, C. F. and Wahl, S. M. 1993. Suppression of arthritis by an inhibitor of nitric oxide synthase. J. Exp. Med 178, 749-754.

24. Menzel, E. J. and Farr, C. 1998. Hyaluronidase and its substrate hyaluronan: biochemistry, biological activities and therapeutic uses. Cancer Lett. 131, 3-11.

25. Moncada, S., Palmer, R. M. and Higgs, E. A. 1991. Nitric oxide: physiology, pathophysiology, and pharmacology.
Pharmacol. Rev. 43, 109-142.

26. Nathan, C. 1992. Nitric oxide as a secretory product of mammalian cells. FASEB J. 6, 3051-3064.

27. Reissig, J. L., Storminger, J. L. and Leloir, L. F. 1995. A modified colorimetric method for the estimation of N-acetylamino sugars. J. Biol. Chem 217, 959-966.

28. Tappel, A. L., Lundberg, W. O. and Boyer, P. D. 1953. Effect of temperature and antioxidants upon the lipoxidase-catalyzed oxidation of sodium linoleate. Arch Biochem Biophys. 42, 293-304.

29. Weisz, A., Cicatiello, L. and Esumi, H. 1996. Regulation of the mouse inducible-type nitric oxide synthase gene promoter by interferon-gamma, bacterial lipopolysaccharide and NG-monomethyl-L- arginine. Biochem J. 316, 209-215.

30. Wiktionary, KaKao-bedeutungserklarungen. http://www. Wiktionary.ory.

\section{초록 : 카카오(Theobroma cacao L.) 용매 분획물의 항산화 및 항염증 효과}

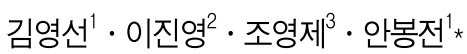

$\left({ }^{1}\right.$ 대구한의대학교 화장품약리학과, ${ }^{2}$ 호서대학교 한방화장품과학과, ${ }^{3}$ 경북대학교 식품공학부 \& 식품생물산 업 연구소)

본 연구는 카카오를 화장품 소재로 활용하기 위하여 항산화 및 항염증 효과를 검증하여 기능성 화장품 소재로 서의 가능성을 검토하였다. 아세톤 추출물을 이용하여 클로로포름층, 에틸아세테이트층, 부탄올층, 물층의 극성 별로 분획을 실시하였다. 카카오 분획물의 전자공여능은 $100 \mathrm{\mu g} / \mathrm{ml}$ 에서 에틸아세테이트 분획물이 $76.2 \%$, 부탄올 분획물이 $53.9 \%$ 의 소거능을 나타내었다. 또한, superoxide anion radical 소거능 측정 결과, 에틸아세테이트 분획 물과 부탄올 분획물이 $50 \mathrm{\mu g} / \mathrm{ml}$ 에서 각각 $76.09 \%, 51.4 \%$ 의 소거능이 나타났고, $\mathrm{Fe}^{2+}, \mathrm{Cu}^{2+}$ 의 첨가에 따른 지방산 패 억제능에서 $\mathrm{Fe}^{2+}$ 를 첨가한 군에서는 에틸아세테이트 분획물이 $50 \mu \mathrm{g} / \mathrm{ml}$ 에서 $64 \%$ 로 $\mathrm{Cu}^{2+}$ 를 첨가한 군보다 저 해능이 높았다. 항염증 효과 측정으로 hyaluronidase 저해 활성을 측정한 결과, 부탄올 분획물의 경우 $100 \mu \mathrm{gg} / \mathrm{ml}$ 에서 $53.04 \%$ 의 저해활성을 나타내었으며, lipoxygenase 저해 활성 측정결과 $10 \mu \mathrm{g} / \mathrm{ml}$ 에서 $51.32 \%$ 의 저해활성을 나타내었다. 대식세포를 이용한 nitric oxide $(\mathrm{NO})$ 저해활성을 측정한 결과 카카오 에틸아세테이트 분획물에서 가장 높은 NO 저해활성을 나타냄을 확인할 수 있었다. 또한 대식세포 내에서 에틸아세테이트 분획물 $100 \mathrm{\mu g} / \mathrm{ml}$ 농도에서 iNOS, COX-2 단백질 발현을 저해하였다. 